\begin{tabular}{l|l|l|l|l}
\hline Volume 1 & Issue 2 & August (2020) & DOI: 10.47540/ijsei.v1i2.53 & Page: $122-131$ \\
\hline
\end{tabular}

\title{
The Social Dynamics of Spirituality and Youthfulness: A Social Interplay Between Disposition and Process
}

\author{
Jonathan James O. Canete ${ }^{1}$, Digvijay Pandey ${ }^{2}$ \\ ${ }^{1}$ De La Salle University, Philippines \\ ${ }^{2}$ Department of Technical Education, IET, India
}

Corresponding Author: Jonathan J.O.C; Email: ncanete976@gmail.com

A R T I C L E I N F O
Keywords: Disposition; Dynamics;
Interplay; Spirituality; Youthfulness.
Received $\quad: 20$ June 2020
Revised $\quad: 02$ July 2020
Accepted $\quad: 08$ August 2020
\begin{abstract}
A B S T R A C T
Issues and topics concerning spirituality are not new in the social sphere. Many great thinkers in the fields of philosophy and theology have tried to excavate the richness of the topic. Though not new a topic, there are still various avenues in the sphere of spirituality that need to be examined and discovered through intellectual abstraction and practical observation. The relevance of spirituality cannot be contained in a specific era nor time frame or even in established social structures because it deals with people and their disposition toward life and a certain desire in their very being for transcendence. In other words, spirituality is all about a person's attitude towards life and a quest for an existential meaning behind every experience that might be of unequaled value or significance. Hence, spirituality is not static but dynamic in its very being, for as long as man desires to go beyond his present state of being and moves into another manner of existence, spirituality is evident; it manifests itself in that affinity for self-transcendence. The term youth, alternatively, also speaks of a dynamic progressive or regressive movement of the self, outside of its present state of being. This study, therefore, is an attempt to phenomenological interpret and appropriate the concept of spirituality as an unfolding of existence on the concept of youthfulness not just an ordinary process in the life of a person wherein one becomes open for self-improvement or self-transcendence.
\end{abstract}

\section{INTRODUCTION}

Issues and topics concerning spirituality are not new in the social sphere. Many great thinkers in philosophy, theology, spirituality, and mysticism have tried to excavate the richness of the topic. Though not new a topic, there are still various avenues in the sphere of spirituality that need to be examined, dis-covered, and cleared out through intellectual abstraction and practical observation; it is a topic that is ancient yet new, an idea suggesting a paradox of time and permanence. The relevance of spirituality cannot be contained in a specific era nor time frame or even in established social structures because it deals with people and their disposition toward life (Puchalski, 2001) and an absolute desire in their very being for and to transcendental reality (Schnell, 2012).

Spirituality is all about a person's attitude towards life and a quest for an existential meaning behind every experience that might be of unequaled value or significance. Hence, spirituality is not static but dynamic in its very being, for as long as man desires to go beyond his present state of being and moves into another manner of existence, spirituality is evident; it manifests itself in that affinity for self-transcendence. The term youth, alter-natively, also speaks of a dynamic progressive or conservative movement of the self, outside of its present state. This study, therefore, is an attempt to phenomenological interpret and appropriate the concept of spirituality as an unfolding of existence on the concept of youthfulness, not just a normal process in the life of a person wherein one becomes open for self-improvement or self-transcendence.

\section{MATERIALS AND METHODS}

The Philosophical approach in exploring the problem present in the terms youthfulness and 
spirituality and explaining the dynamics existing between the two is employed in this paper, for it "deals with the source, nature, and the development of knowledge" (Bajpai) present in this study. Since the approach is philosophical the researcher opted not to result in using the quantitative methods as a viable means in examining the thesis problem and gathering data, instead the researcher deemed it necessary to use the archival research design in collecting and gathering data relevant to the topic being discussed.

Archival research design evolves "primary sources held in an archive, a special collections library, or another repository. Archival sources can be manuscripts, documents, records including electronic records, objects, sound and audiovisual materials, or other materials" (George State University). Moreover, other researchers might refute, challenge, or build an idea out of what this paper has presented using other methodologies that they see fit. In this regard, there are continuous dialectics or ideas and points of view in enriching the topic concerning social media alienation.

\section{RESULTS AND DISCUSSION \\ Spirituality as an Unfolding Movement in Cultural and Societal Existence}

In his book entitled The Spirituality of Revolution, David Tacey (2004) recognizes that spirituality is "a spontaneous movement in society." It is, as it were, a kind of unfolding that takes place in society and not divorced with the dynamic and progressive movement of and in society. In this sense, one cannot but notice that the very movement of spirituality coincides with the movement of society; as society moves, changes, and progresses, so does spirituality. Ernest Burges (1955) identifies that society is continually changing. It is continuously moving forward in a kind of progression.

The progressive movement of society could only be possible if there is also a counterpart of the same quality of movement existing in society. In other words, the quality of movement, whether progressive or regressive, of society determines the state of movement happening within the very bounds of society. If the interior movement in society is of negative quality, it certainly follows that the exterior movement will also be harmful. In this scenario, society's progress is not possible because the interior movement in society is regressing. In Burgess' observation, such movement makes and remakes society or the very opposite of it. Tomofei Gerber (2019) recognizes this movement as the two fundamental Freudian drives - the forces of Eros and Thanatos. The force of Eros is the driving movement that makes society and the force of Thanatos; on the other hand, it is the very force that moves society to recreate itself. Hence, one can postulate that spirituality is the Thanatos or the positive destructive force that moves society forward in attaining a new mode of existence.

The process of creating and recreating suggests the harmonious connection between the forces of construction and destruction. The creation will only be possible in the existence of destruction; there is nothing to create from if there is nothing to destroy first (Dryburgh, 2014). The very force of destruction brings to birth the force of creation, a new paradigm, and a platform of existence. In context, as society progressively moves in remaking itself, it also productively destroys itself in the very process, bringing a new mode and quality of existence, a kind of positive destruction happening within society that is the reason behind the progressive quality of society's movement. In the case of the definitive connection of spirituality and society, the creation of society's new mode of presence is brought by spirituality as the very movement in society.

Furthermore, the movement or force that pushes society forward is the implicit force that tells something about the inward advancement that constructs the very fabric of society; the exteriority in the very forward movement is but an expression of what is happening in the interior scale. Hence, one might say that growth happens from within (Elamin, 2019). The real progress of society, as expressed in its externality, is caused by the progress from within the very being of society.

In this context, if one will postulate the idea of Tacey, one will categorically realize that the reason is behind the progressive movement of society is caused by an equivalent "progressive movement in society." The progress of society as society is due to the development happening within itself. Elahim affirms this in saying that growth happens from within; the external growth or physical and structural growth of a being is but an expression of a progressive movement happening from within. 
The structural, as well as the essential growth of society, is affected by spirituality (Powell \& Steinberg, 2006), the progressive movement from within structural bonds of society. In this sense, there is an intrinsic connection between society and spirituality that forms a certain kind of relationship. The researchers Sail $\mathrm{Oh}$ and Natalia Sarkisian (2011) characterizes this relationship that binds spirituality and society as an engagement of the former to the latter.

Spirituality converges itself with society forming a kind of symbiotic relationship, a relationship of mutual benefits that shapes and constructs each other in the way that the two are almost identical. This commensalism in the relationship between society and spirituality is evident in the progressive movement of society. As the scholar Nancy Finley (1991) points out, this socio-spiritual, symbiotic relationship engages spirituality with the construction of social identity. In return, the established social identity would then shape spirituality as an integral part of such identity. Oh and Sarkisian (2011) called this "contemporary spirituality." It is a kind of spirituality that does not divorces itself with and in society, but rather very much part of it; changing and affects each other in a kind of movement which quality determines the very quality and character of such movement. "Despite customized beliefs and practices, contemporary spirituality is ideologically coherent and transmitted through a process of socialization; thus, it does not imply isolation" (Aupers and Houtman, 2010 in Oh and Sarkisian, 2011). The elements of contemporary spirituality are in the very process of socialization affecting the very textile of society. In other words, through socialization, spirituality affects society, and it is through this same process that society progressively moves. Likewise, socialization is not only a vessel by which spirituality expresses and manifests itself in society, but it is also a fundamental and vital instrument in the formation of society's social distinctiveness. Socialization brings into existence the word culture in which society and "civilization depends on" (Spirkin, 1975); by way of aggregating together and forming connectivity whereby people expressively form their culture.

In this sense, socialization is a coming together in a synodal process of building a specific culture that becomes the principle governing such communion of individualities. Furthermore, Spirkin recognizes the inter-connectivity between culture and society insofar as the former constitutes the latter and, on the other hand, the latter is the very byproduct of the former. The mark of society, thus, is its culture. In context, one could recognize the irrefragability of spirituality in the process of society's cultural identity. Spirituality, as argued by Aupers and Houtman, is very much present in the formation of society's identity.

On the other hand, it has something to do with culture as the form of society as society fashioned by culture. This points out to concept posited above regarding the development in society. The development of society points out to the formation of its identity that has something to do with the development within society. Culture, in this sense, is that "within" society that affects society itself. Culture is also being profoundly affected by spirituality. Hence, spirituality is entrenched in society's cultural identity.

Moreover, spirituality does not only penetrate itself in culture and society but even constructs the former and the change it contains within itself as well. Kim Zimmermann (2017) recognizes that the dynamism culture has pointed out to its everprogressing dimensions, which means to say, this alteration and the evolution of culture brought by a force that affects its various dimensions; cultural movement caused by a force that stirs culture's dimensions. Nevertheless, one might ask about what exactly these dimensions of culture are? Zimmermann provides an acceptable answer to the issue at hand. He (Zimmermann, 2017) maintains that these dimensions are language, music, art, ideology, faith, values, principles, and behavioral patterns Are what constitutes the very essence of culture. Each dimension does not only make culture as an intellectual idea that has nothing to do with the daily praxis of an individual, but it is very speaking about quite the opposite; this makes culture realistic.

The change in culture's essence brought by an equivalent movement that stirs a change in its dimensions. However, what causes the movement in cultural dimensions? In his article, Is Spirituality Necessary? The writer Mike Treder (2011) maintains that spirituality is the prime mover behind the drive-in to each cultural dimension; the change in cultural dimensions is due to the presence of 
spirituality. Spirituality, in a sense, is the primordial force that unfolds culture, employing a change in its dimensions, which, in general, affects society's progressive movement. Therefore, spirituality is the change in society. It paves the way for the change of society, a fundamental change in the very fabric of society that opens an extrinsic change in society. Treder (2011) went on even further by saying that the connectedness of spirituality and culture is unalterable because spirituality tags itself along with the nature of culture as manifested and expressed in its differentiated dynamic dimensions. Thus, spirituality is the actual unfolding movement in cultural and social existence.

\section{Spirituality as an Unfolding of the Self and Beyond Organized Social Structures}

Spirituality is not just a notion signifying a dualism between the realm of idea and praxis, but it's very essence crosses the bridge that separates spirituality and reality. As one sees the way in how spirituality is very much evident in the very movement "of" society, one would also notice that the very movement "in" society is no other than spirituality itself; stirring a change on society's varied dimensions. It is a kind of movement that animates or stirs a change not only in the structural aspect of society but its existence as an entity. Hence, spirituality is relatively evident in reality. Furthermore, it is also plausible to note that spirituality is not only the apparent movement in society. Nevertheless, its presence as the prime mover that initiates the movement of society and all other movements explicit in it transcends time, space, and even culture, the mere byproduct of such movement.

Spirituality cannot be contained and specified. It is a fundamental experience of the self in relation with an existing reality that transcends an individual's point of existence into a new model of existence; forming the very being of the person in the process of existential transition (Lloyd, 2009); a transition of existence between act and potency. In other words, spirituality is beyond a specific timeframe or a particular group, fashioned by cultural evolution and development. However, instead the very word pertains to an experience of existential development (Fuller, 2001) and an affinity towards what T.D Armstrong (1995) calls a transcendental power that deeply affects "how one operates in the world."
Therefore, spirituality as an experience of a profound yearning for self-construction points not on established societal structures but an individual's resiliency for existential self-development in search of personal meaning (Doyle, 1992). Bender and McRoberts (2012) recognize that spirituality has something to do with the "ethical habitus" of an individual. In this thought, spirituality and ethical life are interconnected and interrelated with each other. Bender and McRoberts' definition of spirituality as ethical habitus does not contradict Fuller's thought on spirituality as self-development. The actual notion of self-development means having a morally well-directed life and having such a life is the basis of assessing the quality of life a person has. Therefore, the notion of spirituality is not structured nor a derivative of social construction. However, its very essence is at the heart of a person's yearning for meaning and growth.

Therefore, this makes spirituality a reality beyond the legal bounds of organized religion. Ann Taves (2009, 2013 in Murphy, 2017) argued that "the range of objects, ideas, and practices which are considered religious or sacred is so broad that we cannot speak about "sacred" or religious objects (or concepts). Nevertheless, we should instead talk about objects and ideas that are considered sacred within particular cultural contexts." When speaking and understanding the principles and the faith that animates organized religion, one cannot take away its cultural significance. Taves would appropriate the essence and origin of organized religion as an outcome of a specific cultural context or experience. In other words, religion is an expression of culture (Beyers, 2017), which constitutes society. On the other hand, one cannot take away spirituality in the formation of culture and society's progress. Spirituality, then again, is that force that unfolds or created and animates culture leading to the progressive state of society.

The unfolding and creation of a specific culture is part and parcel. It is the very manifestation, as Doyle (1992) observed, of the self's conscious yearning and search towards personal unfolding and development. Spirituality, therefore, "is an integral part of one's identity and the experience of transcendence of the self, either through religious or secular means" (Murphy, 2017 p. 9). In this case, religion or secularism as parts of 
culture offers a social platform or context to accommodate the self's yearning for transcendence. Therefore, one might realize that spirituality is the yearning of an individual for self-transcendence. Spirituality is not a particular element belonging to either a specific culture and religion or a type of society, simply because spirituality lies on the person who yearns and craves for personal development and transcendence; creating and constructing cultures, and recreating and reconstructing society in the process.

Spirituality is the very disposition or temperament, or in the Thomistic term, the form of the self towards improvement, and the person as the self is the matter of spirituality. The person is the agent, while spirituality is that deep yearning for meaning leading to a way of life that answers the fundamental thirst for self-development and transcendence. Dr. Susan Smalley (2011) realized that the person's yearning for transcendence and self-development creates a way of life as a response to this aspiration of the self that would, in return been institutionalized and became a specific culture, directing and orchestrating the course of society.

In this regard, the advancement or the progressive development of society is caused by spirituality as an integral driving force in the person that sets his temperament towards personal transcendence - consequently, this disposition of personal affinity towards transcendence on the level of the self, fashions cultures. Cultures, as Wendy Griswold (2012) believes, point to a person's way of life. An individual's yearning for selftranscendence, animated by spirituality, forms customs or manners of organizing and directing one's yearning for such existential transcendence. Hence, culture is an expression of that yearning and the probable means in satiating the same desire. This yearning, in return, forms the very concept of society. Society is an aggregation of individualities that are united under one aspiration, which is existential self-transcendence. Therefore, what animates society is the yearning for selfdevelopment or self-transcendence, that generates cultures which is, not just only an expression of that existential aspiration, but also the very means is exhausting such. This movement is the dynamism of spirituality. This dynamism is also present in youth identity as a word behind an identity that unravels and constructs itself in the context of existential development and construction of personal meaning.

\section{Youth Identity as an Unfolding of Existence}

If one tries to look for the definition of the word youth and cultivate the richness of its very meaning, one might end up postulating the definition given by United Nations Educational, Scientific, and Cultural Organization, better known as UNESCO. UNESCO does not categorically define the term youth as a simple noun or an inclusive identity - say being a teacher, a doctor, or even a lawyer. However, instead the term youth has something to do with processes characterized by a constant movement of progression or regression. Youth is a period of transition from childhood dependence to adulthood's independence and awareness of our interdependence as community members. Youth is a more fluid category than a fixed age-group (UNESCO, 2017). With this, one can perceive that the term youth is not a fixed word and does not refer to a specific stage of human existence. Instead, it pertains to a momentary phase in life that is characterized within the spectrum of progression, and wherein a movement suggesting dynamism of existence that eschews the very possibility of definitiveness yet forming a definitive character, in the end, is present. It is a shift of existence or in UNESCO's terms, a period of transition from dependence to inter-dependence. In other words, youthfulness contains within itself change and progression, which makes it an unfolding of existence.

Such unfolding of existence is not an alienable term for the word youth. The illustrious psychologist Erik Erikson believes that each stage in the psychosocial development of human existence builds up in the person a concept of the self or in Erikson's term, the ego identity (cited in Cherry, 2005). The unfolding of existence is palpable in every stage of Erikson's psychosocial development, as each contributes to the enrichment of the ego. However, the paroxysms of such unfolding lie in the fifth stage, Wherein the person enriches his ego identity and social identity through personal exploration of interdependence with others. Ego identity is the conscious sense of self that we develop through social interaction (Loue, 2008). Kendra Cherry (2005) added that such exploration of the self would not only determine one's role in society but could also influence the 
behavior of an individual "for the rest of his life." The unfolding of existence in this stage in the development of the person is crucial because the kind of identity that one forms determine the kind of person he will become in the future. Therefore, the exploration of oneself affects not only an individual but the society as well.

Saul McLeod (2013) believes that the fifth stage is apparent within adolescence, from about 12-18 years old, and the search for self-identity is also evident. Conversely, the United Nations (UN) mentioned that for statistical consistency across regions, defines 'youth,' as those persons between the ages of 15 and 24 years (UNESCO, 2017). Here, one is being introduced and might be confused with two different yet intertwined age brackets, one from McLeod and one from the UN. If one will follow the definition of UNESCO on the word youth, one can notice that there is no difference between the meaning behind McLeod's age bracket and that of the United Nations, nor there is an apparent alteration between the term adolescence and the term youth. McLeod might be using the term adolescence differently from how the UN uses it; the sense between the terms is the same. The adolescent mind is essentially a mind or moratorium, a psychosocial stage between childhood and adulthood, and between the morality learned by the child, and the ethics to be developed by the adult (Erikson, 1963). The term youthfulness speaks of adolescence, and adolescence speaks of youthfulness.

The youth, therefore, is in a crucial stage wherein the person goes on exploration, informing his ego identity or the sense of the self, which in turn would affect the present state of his existence and shape its future state. What the youth learns in this stage of ego development and the exploration of the self, is that he is in the delicate process of selfbecoming. Such self-becoming unfolds the existence of "a new person that either benefit or harm existing people (Broome \& Morton, 1994, p. 168). A person may either be the future of society or the very opposite of that.

The kind of self-becoming a youth undergoes is vital enough to determine his probable role in society. With this, the environment is the determinant factor that plays a vital role in the youth's unfolding process. The kind and the sense of environment the youth situates himself in will heavily influence the unfolding of a person. Arora, Shah, Chaturvedi, \& Gupta (2015) noticed that youth is very vulnerable to various factors that constitute his environment. If the environment is not ideal, the youth then will only be just a fractured person who aspired to be whole (Coughlin, 2003, p. 6 ) and is trying to look for his role in society. The society, where the youth was into, is not just an ordinary environment but also a particular plain where the formation and transformation of persons take place; it is like a cocoon where the delicate process of incredible recreation and the horror of deformation takes place. Carl Rogers, the founder of the humanistic approach in psychotherapy, emphasized the importance of the environment as a factor in the development of every individual, especially the youth.

Seeing the definition of spirituality not as a defined identity but as a self-becoming process, one can now post a question about the parallelism of the word youth with the concept of spirituality. Is there a relationship between the two ideas? Are they parallel? Can one make an association of ideas between spirituality and the term youth, or are they just two independent and univocal terms that cannot be associated with one another?

\section{Spirituality and Youthfulness: Disposition and Process}

The concepts of spirituality and youthfulness are closely related to each other. Murphy (2017) argued that spirituality does not detach itself from the sense of the self of an individual. Spirituality is the inner disposition by which the individual yearns for self-transcendence or self-unfolding. Furthermore, it could also be the very way of life of the same person who aspires for personal transcendence. In this regard, scholars J.M. Salsman and C.R. Carlson (2005) plausibly contended that spirituality is intrinsic and extrinsic. The "intrinsic" of spirituality lies in the very aspiration for a person to go beyond his present state of existence; it is a transition of existence. While the "extrinsic" of spirituality comes as the very response of the person from what he aspires for, the aspiration of an individual for a better existence enables him to create a certain kind of way on how to concretize or to make present the aspiration of existential selftranscendence; creating cultures and society in the very process. For Elsie Jones-Smith (2014), spirituality is a "force" that drives a person to 
recreate himself and provide the manner and platform of how such recreation could be possible. In other words, it is a creating force that fashions both the person, who aspires to be better, and the environment that such desire takes place.

Youthfulness, on the other hand, is not a definitive identification of an individual, not just a normal part of a particular social group. However, it is as stated earlier that the very term "youth" means a momentary phase in human life wherein the person's identity is being fashioned or formed (Cherry, 2005). In other words, the term youth has something to do with the formation of the self. In this sense, one can find a correlation between the idea of spirituality and the word youth. Erik Erikson (1970) observed that during the phase of youthfulness, a person experiences several changes not only with the physical domain of his existence but also with the domains of psychology. In other words, the term youth is almost synonymous with the word change, for it depicts change and transition. Likewise, it also pertains to a kind of vulnerability of the person towards the invasiveness of the word change. It is at this stage that a person becomes utterly vulnerable.

The concept of the self is quintessentially being formed and informed in the consciousness of the person. In other words, the vulnerability of the self comes from the moment wherein the person forms his identity and constructs his ideologies. Hence, a young person is fragile, in the sense that whatever he learns and discovers in this stage of sheer vulnerability would affect his being, his becoming a kind of depending on the very process of youthfulness and the environment where it operates. This mere vulnerability is the reason being behind the ethical and unethical behavior of an individual. Gabbey and Jewell (2019) implicitly argued that the quality of behavior that a person exhibit defines the kind of unfolding that he has in the process of youthfulness. In other words, who and what a person will be, mainly resting on what transpires on the process of youthfulness. In this regard, one can see that the term youthfulness does only speak of vulnerability or a simple process in the formation of the sense of the self. However, it also speaks of personal transcendence and unfolding.

Youthfulness as personal transcendence and unfolding speaks of the nature of spirituality. As argued earlier, spirituality points to the individual's temperament for personal progress, which qualitatively speaks of the transcendence of the self towards a new mode of existence. In this sense, one can indubitably argue that there is an intrinsic connection between spirituality and youthfulness. Pope Francis (2019), in his apostolic exhortation Christus Vivit, plausibly calls the youth people not only the future of humanity but as "its present." The pope would ascribe the present tense with the term youthfulness; this speaks of the term, not as a static identity but an ever-dynamic one. It is a moment in a person's life that is ever uncluttered to change. Francis would go even further by saying the term "youth does not exist there exist only young people, each with the reality of his or her own life (par. 71). The term youth is not an ordinary idea signifying nothing, but its value is in the very person himself; the term youth is not just a term; it is a person. In this aspect, the term youth speaks of the person in the process of self-becoming. According to Francis, such self-becoming could rebuild society from the ashes of disfigurement caused by corrupt adults (Sarandrea, 2014).

Hence, one can argue that the term youth not as an empty concept but as a person would refer to spirituality. Both spirituality and youthfulness have something to do with the concept of the self. In the stage of youthfulness, the sense of self of a person forms. A person in this stage forms his identity and his probable role in society, hence depicting a certain kind of natural affinity to change but also a vulnerability to external influences. On the other hand, what drives a person to transcend the present state of his existence is no other than spirituality. In context, the very temperament or disposition of a person for self-development is spirituality, while the process wherein one becomes vulnerable and open to change is youthfulness. The affinity towards selftranscendence speaks of spirituality, and the process of vulnerability for such transcendence is youthfulness. Thus, this is what Francis (2019) mentioned in Christus Vivit that whoever is open to change is considered a young person regardless of age. Youthfulness is a process of sheer vulnerability or openness to change and self-development.

Both spirituality and youthfulness play a pivotal role not only in the person but also in society. Spirituality opens a person's horizon to continually improving himself and reveals the very 
richness that lies within his very being. It encourages a person to enter the process of sheer vulnerability and affinity to change in order to excavate the various potentialities that enshrined in his very person. A person who desires selftranscendence consciously and freely throws himself into the process of youthfulness. His very being becomes vulnerable to the constructive force of Freudian Eros and Thanatos. The aftermath of the process is a renewed sense of the existential self that transcends the previous self that makes an "adult" and makes the same person a "young" individual. Thus, a transcendent self is a young individual while a conventional person. $\mathrm{He}$ is an adult individual; who eschews every possibility for self-transcendence or development. In context, in the course for self-transcendence, one cannot take away the existence and importance of spirituality and youthfulness. They are two forces working together and present in each other. They are the two forces that interplay with each other in the desire of a person to be the better version of himself.

\section{CONCLUSION}

St. John Paul II (in Tranzillo, 2013) argued that a person is full of potentialities and capacities. His meaning derives from the very unfolding of these potentialities and the proper application of his capacities. The full sense of the self is a dream come true for the aspiring person if his aspiration kisses the life situation; dreams become a reality. Moreover, spirituality and youthfulness make this aspiration tangible. As a person enters the portals of self-development and becomes vulnerable to change, his does not only shapes his very being in the process but also creates cultures by which to direct the course of the transcendent-self and in the long run shapes society at large. A developed society is a society of developed youthful persons.

\section{REFERENCES}

Armstrong, T. D. (1995). Exploring Spirituality: The development of the Armstrong measure of spirituality. Paper presented at the annual convention of the American Psychological Association. Retrieved from New York, NY

Arora, S., Shah, D., Chaturvedi, S., \& Gupta, P. (2015). Defining and Measuring Vulnerability in Young People. Indian
Journal of Community Medicine, 40(3), 193-197. doi:10.4103/0970-0218.158868 Aupers, S., \& Houtman, D. (2010). Beyond The Spiritual Supermarket: The Social And Public Significance Of New Age Spirituality. Religions of Modernity: Relocating the Sacred to the Self and the Digital, 135-160. doi:10.1163/ej. 9789004184510.i-273.54

Bajpai, Naval. Business Research Methods. kindle ed., Pearson Education India, 2011.

Bender, C., \& McRoberts, O. (2012). Mapping a Field: Why And How to Study Spirituality. Social Science Research Council Working Papers, 1-27.

Beyers, J. (2017). Religion and culture: Revisiting a close relative. HTS Theological Studies, 73(1).

Broome, J., \& Morton, A. (1994). The Value of a Person. The Aristotelian Society, 68, $167-$ 185+187-198.

Burgess, E. W. (1955). Our Dynamic Society and Sociological Research. The Midwest Sociologist, 17(1), 3-6.

Cherry, K. (2005, October 10). Understanding Erikson's Stages of Psychosocial Development. Retrieved from https://www.verywellmind.com/erikeriksons-stages-of-psychosocialdevelopment-2795740

Coughlin, J. (2003). Canon Law and the Human Person. Journal of Law and Religion, 19(1), $1-58$.

Doyle, D. (1992). "Have we looked beyond the physical and psychosocial? Journal of Pain and Symptom Management, (7), 302-311.

Dryburgh, A. (2014, July 30). Creation Or Destruction? They are The Same Thing. Retrieved from https://www.forbes.com/sites/alastairdrybur gh/2014/07/30/creation-or-destructiontheyre-the-same-thing-really/

Elamin, E. (2019, June 1). Breatharian Goddess: Meditation is the Foundation. Retrieved from http://elixirfield.blogspot.com/2019/06/breat harian-goddess-talk-by-elitom.html

Erikson, E. H. (1970). Reflections on the dissent of contemporary youth. International Journal of Psychoanalysis, 51, 11-22. 
Erikson, E. H. (1963). Youth: change and challenge. New York: Basic Books.

Finley, N. J. (1991). Political Activism and Feminist Spirituality. Sociological Analysis, 52(4), 349. doi:10.2307/3710851

Fuller, R. C. (2001). Spiritual, But Not Religious: Understanding Unchurched America. Oxford, England: Oxford University Press on Demand.

Gabbey, A., \& Jewell, T. (2019). Aggressive Behavior. Retrieved from https://www.healthline.com/health/aggressiv e-behavior\#outlook

George State University. "Archival Research: Why Archival Research?" GSU Library Research Guides at Georgia State University, George State University Library, 9 Dec. 2019, research.library.gsu.edu/archivalresearch. Accessed 19 June 2020.

Gerber, T. (2019, February 16). Eros and Thanatos: Freud's two fundamental drives. Retrieved from https://epochemagazine.org/eros-andthanatos-freuds-two-fundamental-drives50a $82 \mathrm{a} 11 \mathrm{a} 389$

God Ministries Inc. (2010, February 26). Spirituality. Retrieved from https://www.allaboutspirituality.org/spiritual ity.htm

Griswold, W. (2012). Cultures and Societies in a Changing World. Thousand Oaks, CA: SAGE.

Hodge, D. (2012). The Conceptual and Empirical Relationship Between Spiritual and Social Justice: Exemplars from Diverse Faith Traditions. Journal Of Religion \& Amp; Spirituality in Social Work: Social Thought, (31), 32-50. doi:10.1080/15426432.2012.647878

Jones-Smith, E. (2014). Theories of Counseling and Psychotherapy: An Integrative Approach. Thousand Oaks, CA: SAGE Publications.

Lloyd, I. (2009). Self-Transcendence. Retrieved from

https://www.sciencedirect.com/topics/neuro science/self-transcendence

Loue, S. (2008). Identity. In Encyclopedia of Aging and Public Health (p. 453). Berlin, Germany: Springer Science \& Business Media.
McLeod, S. (2013, September). Erikson's Psychosocial Stages of Development. Retrieved from https://www.simplypsychology.org/ErikErikson.html\#identity

Murphy, J. (2017). Beyond "Religion" and "Spirituality": Extending a "Meaning Systems" Approach to Explore Lived Religion. Archive for the Psychology of Religion, 39(1), 1-26. doi:10.1163/15736121-12341335

Oh, S., \& Sarkisian, N. (2011). Spiritual Individualism or Engaged Spirituality? Social Implications of Holistic Spirituality among Mind-Body-Spirit Practitioners. Sociology of Religion, 73(3), 299-322. doi:10.1093/socrel/srr054

Pope Francis. (2019, March 25). "Christus Vivit": Post-Synodal Exhortation to Young People and the entire People of God. Retrieved from http://w2.vatican.va/content/francesco/en/ap ost_exhortations/documents/papafrancesco_esortazioneap_20190325_christus-vivit.html

Powell, W. W., \& Steinberg, R. (2006). The Nonprofit Sector: A Research Handbook (2nd ed.). New Haven, CT: Yale University Press.

Puchalski, C. M. (2001, October 14). The role of spirituality in health care. Retrieved from https://www.ncbi.nlm.nih.gov/pmc/articles/ PMC1305900/

Roof, W. (1993). A Generation of Seekers: The Spiritual Journeys of the Baby Boom Generation. San Francisco, CA: Harper.

Salsman, J. M., \& Carlson, C. R. (2005). Religious Orientation, Mature Faith, and Psychological Distress: Elements of Positive and Negative Associations. Journal for the Scientific Study of Religion, 44(2), 201-209.

Sarandrea, L. V. (2014, October 30). Corruption explained to children and adults. Retrieved from http://www.kg.undp.org/content/kyrgyzstan/ en/home/ourperspective/ourperspectivearticl es/2014/10/30/corruption-explained-tochildren-and-adults.html 
Schnell, T. (2012). Spirituality with and without Religion-Differential Relationships with Personality. Archive for the Psychology of Religion, 34, 36-61.

Smalley, S. (2011, November 17). Spirituality As A Way of Life. Retrieved from https://www.huffpost.com/entry/spiritualityas-a-way-of_b_454766

Spirkin, A. (1975). Dialectical Materialism. Themes in Soviet Marxist Philosophy, 5-47. doi:10.1007/978-94-0101873-9 2

Stanczak, G., \& Miller, D. (2004). “Engaged Spirituality: Spirituality And Social Transformation in Mainstream American Religious Traditions. Los Angeles, CA: Center for Religion and Civic Culture.

Tacey, D. J. (2004). The Spirituality Revolution: The Emergence of Contemporary Spirituality. London, England: Psychology Press.

Taves, A. (2009). Religious Experience Reconsidered: A Building-Block Approach to the Study of Religion and Other Special Things. Princeton, NJ: Princeton University Press.

Teves, A. (n.d.). Building blocks of sacralities: A new basis for comparison across cultures and religions. In R. F. Paloutzian \& C. L. Park (Eds.), Handbook of the psy- chology of religion and spirituality (2nd ed.). New York, NY: Guilford Publications.

Tranzillo, J. (2013). John Paul II on the Vulnerable. Catholic University of America Press, 354.

Treder, M. (2011, March 2). Is 'Spirituality' Necessary? Retrieved from https://ieet.org/index.php/IEET2/more/trede r20110302

UNESCO. (2017). Youth - Definition. Retrieved from http://www.unesco.org/new/en/socialand-human-sciences/themes/youth/youthdefinition/

Zimmermann, K. (2017, July 12). What Is Culture? Retrieved from https://www.livescience.com/21478-whatis-culture-definition-of-culture.html 